Monograf :

KAJIAN AKADEMIS TERHADAP PEMBENTUKAN

KABUPATEN INDRAGIRI SELATAN

(PROSPEKTIF PEMBENTUKAN DAERAH MENURUT

PERATURAN PEMERINTAH NOMOR 78 TAHUN 2007)

KMS. Novyar Satriawan Fikri

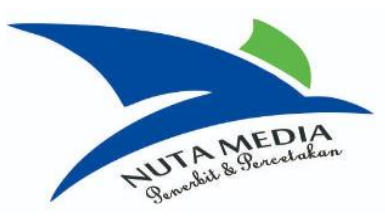




\section{Monograf : \\ KAJIAN AKADEMIS TERHADAP PEMBENTUKAN \\ KABUPATEN INDRAGIRI SELATAN \\ (PROSPEKTIF PEMBENTUKAN DAERAH MENURUT \\ PERATURAN PEMERINTAH NOMOR 78 TAHUN 2007)}

Nuta Media, Yogyakarta

Ukuran. $15 \times 23$

Halaman $92+$ vi

Cetakan : I, September 2021

ISBN : : : : $\quad$ :

Penulis $\quad:$ KMS. Novyar Satriawan Fikri,SH.MH

Editor $\quad:$ Dr. Mulono Apriyanto

Sampul : latif azhad mustofa

Layout $\quad: \mathrm{NuNaNev}$

Diterbitkan oleh :

Nuta Media

Jl. P. Romo, No. 19 Kotagede Jogjakarta/

Jl. Nyi Wiji Adhisoro, Prenggan Kotagede Yogyakarta

nutamediajogja@gmail.com; 081228153789

@2021, Hak Cipta dilindungi undang-undang, dilarang keras menterjemahkan, memfotokopi atau memperbanyak sebagain atau seluruh isi buku ini tanpa izin tertulis dari penerbit

ISI DI LUAR TANGGUNGJAWAB PENERBIT DAN PERCETRAKAN dicetak olah : Nuta Media 


\section{Kata Pengantar}

Puji Syukur Kehadirat Allah SWT atas segala limpahan Hidayah dan RahmatNya karena dengan kebesaran-Nya penulis dapat menyelesaikan penulisan buku monograf dengan judul KAJIAN AKADEMIS TERHADAP PEMBENTUKAN KABUPATEN INDRAGIRI SELATAN (PROSPEKTIF PEMBENTUKAN DAERAH MENURUT PERATURAN PEMERINTAH NOMOR 78 TAHUN 2007). Penulisan buku monograf ini didasarkan dari hasil penelitian penulis dengan judul ANALISIS PROSPEKTIF PEMBENTUKAN DAERAH MENURUT PERATURAN PEMERINTAH NOMOR 78 TAHUN 2007 (KAJIAN AKADEMIS TERHADAP PEMBENTUKAN KABUPATEN INDRAGIRI SELATAN).

Buku monograf ini diharapkan bisa menjadi tambahan referensi bagi para akademisi dan masyarakat pada umumnya dalam rangka menambah khasanah pengetahuan tentang perbaikan mutu biji kakao petani.

Penulis tentunya menyadari bahwa dalam penulisan buku monograf ini masih banyak kekuarangan sehingga saran dan kritik diterima dengan lapang. Terakhir, semoga buku monograf ini memberikan manfaat bagi semua. Aamiin.

Pekanbaru, 2021

Penulis 


\section{BAB VIII. PENUTUP}

Adapun yang menjadi faktor pendorong rencana pemekaran wilayah Indragiri Bahagian Selatan adalah dikarenakan adanya keinginan untuk peningkatan kualitas hidup masyarakat, baik secara sosiokultural, politik maupun ekonomi. Oleh karena itu, walaupun pembentukan daerah otonombaru akan meningkatkan biaya penyelenggaraan pemerintahan, namun diharapkan akan:

- Meningkatkan kualitas dan pemerataan pelayanan kepadamasyarakat;

- Meningkatkan percepatan pembangunan ekonomi, terutama padadaerah pinggiran;

- Memfasilitasi pertumbuhan kehidupan demokrasi di daerah;

- Meningkatkan keamanan dan ketertiban di daerah;

- Memberikan kontribusi bagi persatuan dan kebangsaan (nation building);

Proses Pembentukan Kabupaten Baru harus mengacu kepada Peraturan Pemerintah Nomor 78 Tahun 2007 Tentang Tata Cara Pembentukan, Penghapusan, Penggabungan Daerah, di dalam Pasal 4 Peraturan Pemerintah Nomor 78 Tahun 2007 dijelaskan bahwa Pembentukan daerah kabupaten/kota berupa pemekaran kabupaten/kota dan penggabungan beberapa kecamatan yang bersandingan pada wilayah kabupaten/kota yang berbeda harus memenuhi syarat administratif, teknis, dan fisik kewilayahan. 


\section{DAFTAR PUSTAKA}

\section{A. Buku-Buku}

AP Le Sueur dan JW Herberg, Constitutional \& Administrative Law, Cavendish Publishing Limited, London, 1995.

Bagir Manan, Politik Hukum Otonomi Daerab Sepanjang Peraturan PerundangUndangan Pemerintahan Daerah, Dalam Martin Hutabarat, Et, Al, Hukum dan Politik Indonesia : Tinjauan Analisis Dekrit Presiden dan Otonomi Daerah, Sinar Harapan, Jakarta, 1996.

Budi Agustono, "Otonomi Daerah dan Dinamika Politik Lokal: Studi Kasus di Kabupaten Deli Serdang, Sumatera Utara" dalam Desentralisasi Globalisasi dan Demokrasi Lokal, editor Jamil Gunawan, LP3ES, Jakarta, 2005.

C Smith, Territorial Dimension Of The State. Cambrige University Press, 1986 Bondan Hermanislamet, Desentralisasi Perencanaan Pembangunan dan Otonomi Daerah dalam Jurnal Forum Perencanaan PembangunanPuslitPerencanaan Pembangunan Nasional UGM : Yogyakarta, 1993.

Cheema, G. Shabbir and A. Rondinelli (Eds.), Decentralization and Development Policy Implementation in Developing Countries, Sage Publication, 1983.

Desy Anwar, Kamus Besar Bahasa Indonesia, Amelia, Surabaya, 2003.

Djohermansyah Djohan, "Mengkaji Kembali Konsep Pemekaran Daerah Otonom”, dalam Indra J. Piliang, M. Zaki Mubarak dkk, Blue Print Otonomi Daerah Indonesia, Jakarta : Yayasan Harkat Bangsa -Partnership, 2006.

Duguit, Traite" de Droit Constitutional, 1923

Franz Magnis Suseno. Mencari Sosok Demokrasi, Gramedia, Jakarta, 1995.

Friedrich, Man And His Goverment, An Empirical Theory of Politics, New York :

Mc Graw Hill Book Coy Inc 1963

E. Herman, "Menangkap Momentum Otonomi Daerah" Pekanbaru : UNRIPress, 2002.

Gabriele Ferrazzi, „International Experiences in Teritorial Reform-Implications For Indonesia” USAID-DRSP, Januari 2007.

George Jellinek, Allgemeine Staalhere, Berlin, 1914.

Husein Umar, Metode Penelitian untuk Skripsi dan Tesis Bisnis Edisi Kedua, Rajawali Pers, Jakarta, 2008. 
Hans Antlov, Beyond Poverty Reducation : Promoting a Comprehensive Social Policy Framework for Desentralized". Makalah dipresentasikan pada prakarsa conference di Jakarta, 2007

Hill and Williams, The Economi and Social Dimensions of Regional Development in Indonesia. Ekonomi dan Keuangan Indonesia, 1989.

Jazim Hamidi dkk, Teori dan Politik Hukum Tata Negara, Total Media, Yogyakarta, 2009.

Jose Riwo Kaho, Prospek Otonomi Daerah di Negara Republik Indonesia, Identifikasi Beberapa faktor yang mempengarubi penyelenggaraannya, Raja Grafindo Persada, Jakarta, 2001.

Prospek. Otonomi Daerah di Negara Republik Indonesia, Jakarta : PT. Raja Grafindo Persada, 2005

Kendra Clegg, "Dari Nasionalisasi ke Lokalisasi: Otonomi Daerah di Lombok" dalam Desentralisasi Globalisasi dan Demokrasi Lokal, editor JamilGunawan, LP3ES, Jakarta, 2005.

Mariam Budiardjo. Dasar-dasar Ilmu Politik, PT Gramedia Pustaka Utama, Jakarta, 1997.

Michael Malley, "Daerah Sentralisasi dan Perlawanan" dalam Donald K. Emmerson (ed.), Indonesia Beyond Soeharto: Negara, Ekonomi, Masyarakat, Transisi, PT Gramedia, Jakarta, 2001.

M.L Jhingan, Ekonomi Pembangunan dan Ekonomi

Perencanaan.Terjemahan,Penerbit Rajawali, Jakarta, 1992.

M. Busro Muqodas. Politik Pembangunan Hukum Nasional, UII

Press, Yogyakarta, 1992.

Osborne \& Gaebler, Reinventing Government: How the Entrepreneurial Spirit is

Transforming The Public Sector, Terjemahan: Abdul Rosyid, Jakarta: Pustaka Binaman Pressindo, 1997.

Pratikno, Usulan Perubahan Kebijakan Penataan Daerah (Pemekaran Dan Penggabungan Daerah, Policy Paper, 2008,

Ridwan HR, Hukum Administrasi Negara, Raja Grafindo Persada, Jakarta, 2008.

Robert Bennett, Local Government and market decentralization: Experiences in industrialized, developing and former Eastern bloc countries, United Nations University Press, 1994.

Syamsudin, dkk, Iklim Investasi Daerah, GTZ-RED, Jakarta, 2007.

Sufian Hamim, dkk, Kajian Pemekaran Kabupaten Indragiri Hilir, UNISI, 2010. Tri Ratnawati \& Cahyo Pamungkas, Pemekaran Daerah Dalam Perspektif

Nasional, Pustaka Nasional, 2009. 
Tamrin Amal Tomagola, „" Pengelolaan Konflik Komunal Dalam Pemekaran Daerah”, Makalah. Jakarta, 2006

USAID-DRSP, "Desentralization 2006 : Stock Taking On Indonesia"s Recent Desentralization Reforms”, Jakarta, 2006.

\section{B. Undang-Undang}

Undang-Undang Dasar 1945 Amandemen Ke IV

Undang-Undang Nomor 32 Tahun 2004 Tentang Pemerintahan Daerah

Peraturan Pemerintah Nomor 78 Tahun 2007 Tentang Tata Cara

Pembentukan,Penghapusan dan Penggabungan Daerah.

\section{Internet}

Arif Roesman Effendy. Pemekaran WilayahKabupaten/Kota.

Http/www.google.com, 10 Mei 2010. Jam 11.00 Wib.

Edi Suharto, Peta dan Dinamika Welfare State di Beberapa Negara: Pelajaran Apa

Yang Bisa Dipetik Untuk Membangun Indonesia, 2010, Http/www.Google.com. 13 Mei 2010. Jam 21.00 Wib.

Fenti Efendy. Demokrasi Indonesia. Http/www.google.com. 11 Mei 2010. Jam 11.00 Wib.

Khairul Fahmi. Problematika Pembentukan Daerah Baru. Http/www.google.com,10 Mei 2010. Jam 11.00 Wib.

Rizky Argama. Pemberlakukan Otonomi Daerah dan Fenomena Pemekaran Wilayah Di Indonesia. Http/www.Google.com, 10 Mei 2010. Jam 10.00 Wib.

Togap Simangunsong, Win-win Solution Pemekaran Daerah, Http/www.Google.Com. 17 Januari 2011, Jam 10.30 Wib

Http/www.Google.Com, Kebijakan Otonomi Daerah Sebagai Bentuk Demokrasi Dalam Upaya Meningkatkan Kesejabteraan Rakyat, Tanggal 16 Maret 2011, Jam 19.30 Wib.

D. Jurnal

KMS Novyar Satriawan Fikri, and Ali Azhar. "Academic Study Of District Formation South Indragiri." Progressive law review 2.01 (2020): 1-13.

KMS Novyar Satriawan Fikri. "Herdiansyah, 2019. To Fighting The Covid 19 Virus In Indragiri Hilir." Jurnal Hukum DAS SOLLEN3 (2): 23-45.

KMS Novyar Satriawan Fikri, J. (2021). Juridical Review of Regional Regulation Number 50 of 2020 Concerning Health Protocols as a Prevention and 
Control of Corona Virus Disease 2019 in Indragiri Hilir District. Annals of the Romanian Society for Cell Biology, 25(6), 5506-5517.

KMS Novyar Satriawan Fikri., \& Rahmah. (2018). Pelaksanaan Pemekaran Kecamatan Sentajo Raya Kabupaten Kuantan Singingi Menurut Peraturan Pemerintah Nomor 19 tahun 2008 Tentang Kecamatan (Studi Terhadap Pasal 4 Huruf C dan D). Jurnal Hukum Das Sollen, 2(1). 


\section{Sinopsis}

Rezim Orde Baru mewujudkan kekuasaan sentripetal, yakni berat sebelah memihak pusat bukan pinggiran (daerah). Daerah yang kaya akan sumber daya alam, ditarik keuntungan produksinya dan dibagi-bagi di antara elite Jakarta, alihalih diinvestasikan untuk pembangunan daerah. Akibatnya, pembangunan antara di daerah dengan di Jakarta menjadi timpang.

Pada masa awal reformasi, selain adanya keinginan provinsi memisahkan dari republik, juga bermunculan aspirasi dari berbagai daerah yang menginginkan dilakukannya pemekaran provinsi atau kabupaten. Dalam upaya pembentukan provinsi dan kabupaten baru ini, tarik-menarik antara kelompok yang setuju dan tidak setuju terhadap pemekaran daerah sebagai akibat dari otonomi daerah meningkatkan suhu politik lokal. Otonomi daerah, di lain pihak, memperkenalkan kecenderungan baru, yaitu banyaknya lembaga sosial masyarakat baru yang bertujuan untuk mengatasi konflik, perbedaan etnis, dan masalah sosial-ekonomi dengan bantuan minimal dari pemerintah lokal. Pemerintah lokal juga mencoba mengadopsikan peran aktif mengasimilasi kepentingan golongan minoritas. Perkembangan masyarakat pada era reformasi, muncul dengan adanya keinginan masyarakat pada berbagai wilayah untuk membentuk daerah otonom baru (baik Provinsi, Kabupaten maupun Kota) yang terpisah dari daerah induknya.

Pemekaran daerah merupakan implementasi dari pembentukan daerah- daerah otonomi baru. Penjelasan umum Undang-Undang Nomor 32 Tahun 2004 menyatakan bahwa pembentukan daerah pada dasarnya dimaksudkan "untuk meningkatkan pelayanan publik guna mempercepat terwujudnya kesejahteraan masyarakat disamping sebagai sarana pendidikan politik di tingkat lokal." pelaksanaan pemekaran daerah, PP Nomor 78 Tahun 2007 telah mengatur tentang bagaimana proses pemekaran daerah yang harus dilalui dan syarat-syarat yang mesti dipenuhi.

Diakhir semoga buku ini dapat menambah kasanah mengenai perundangan pemekaran daerah serta syarat-syaratnya. 